\title{
CYBER LOAN SHARKS, SOCIAL
CREDIT, AND NEW FRONTIERS
OF DIGITAL CONTROL Nicholas Loubere
}

$\mathrm{I}^{\mathrm{N}}$

N RECENT YEARS, China's rapidly evolving digital sphere has paradoxically been the site of both liberation and oppression. The development of the Chinese Internet has been characterised by openness and inclusivity - with the number of netizens in the country multiplying at an exponential rate. At the same time, however, Internet activity has increasingly been subjected to governmental restrictions aimed at controlling how the country's digital space can be used. The sudden emergence of Internet finance in China is emblematic of this contradictory cyber landscape. In only a few years, China has become the world's largest online lending market, fuelling new forms of economic growth. At the same time, however, the rise of Internet finance has pushed governmental regulators to their limits as they seek to control rampant fraud and illegal behaviour in an attempt to engineer a more ‘trustworthy' society.

\section{Loan Sharking 2.0}

In June 2016, reports emerged that Chinese female university students who borrowed money through Jiedaibao 借 贷宝 - a popular online peer-to-peer (P2P) lending platform (see the China Story Yearbook 2014: Shared Destiny, Information Window 'The Rise of Chinese Internet Finance', p.27) - were 


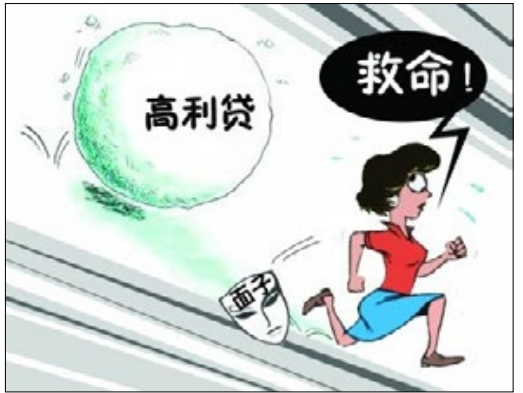

A woman cries for help as she runs from a gaolidai snowball

Source: money.163.com

being coerced into providing photos of themselves naked to secure high-interest loans. When the borrowers were unable to repay their debts, the lenders threatened to send the photos to their friends and families. Subsequent journalistic investigations of this 'naked borrowing'裸条借贷 revealed that the practice was common. ${ }^{1}$

For many, this story crystallised the 'wild west' nature of China's emerging digital financial landscape. With the country's rapidly expanding and diversifying online lending industry often slipping through the regulatory cracks, China's 'cyber loan sharks' (gaolidai 高利贷) operate in a legal grey zone with seeming impunity. New and shifting power dynamics have upended the traditional rules and norms of control underpinning China's financial industry, and society more broadly.

\section{Disruptive Innovation or Dangerous} Chaos?

Controlling young women's bodies through debt is an extreme example of the ways in which lenders leverage their power to ensure repayment and to mitigate risk in China's digital financial market. The unprecedented growth of Internet finance in China over the past decade has resulted in a great number of ventures using a variety of techniques, not all of them salubrious, to provide a wide range of products. Depending on one's perspective, this dynamic new industry could be characterised as either disruptively innovative or dangerously chaotic.

of particular concern for regulators is the P2P market, which is already the largest in the world. In 2016, it was estimated that P2P lenders in China would handle up to two trillion yuan in loans, provided across more than 5,800 platforms. $^{2}$ Some of these P2P providers handle extensive portfolios. For instance, Paipaidai 拍拍贷, which became the country's first P2P lender when it was established in 2007, has over 1.2 million active members (including borrowers and lenders). This is a major shift for a financial system that has until recently been tightly controlled, regulated, and largely owned by the state. The Chinese financial 
system has traditionally been characterised by state-mandated, below-market interest rates. At the same time, onerous lending requirements made it difficult for individuals, households, or small and medium enterprises without the right connections to get access to credit. The P2P lending industry has based its rapid growth on coming up with innovative ways to provide credit to this largely untapped market.

This massive new digital P2P industry features highly diverse entities operating online platforms. These include traditional financial institutions, new online-only start-ups, and even previously illegal underground banks that can now operate in the P2P grey zone. Some of these platforms, such as Paipaidai and Renrendai 人人贷, serve only as an intermediary, facilitating direct transactions between the lender and the borrower. However, there is a wide variety in the types of credit offered by these providers, ranging from tiny microloans for personal consumption or microenterprises, to billions of yuan for huge state-owned enterprises (SOEs). There are also indirect lending platforms where investors pool funds for lending, although recent legislation has restricted their activities. Sometimes these funds go through a number of 'asset transformations', ${ }^{3}$ obscuring

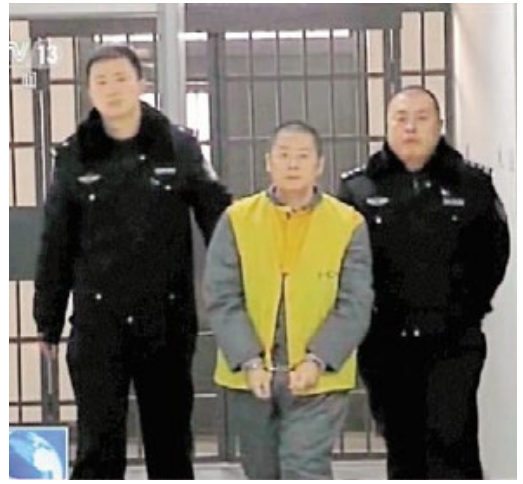

Ezubao's founder Ding Ning: multi-billion-dollar Ponzi scheme Source: CCTV

risks and making it difficult to trace the origin of the finance.

Diversity, quantity, and the relative lack of oversight has resulted in high levels of risk and even outright fraud. It has been reported that up to one third of P2P lenders are in financial difficulty or are involved in dubious activities. ${ }^{4}$ At least three large P2P platforms - Ezubao e 租宝, Zhongjindai 中金贷, and Rower P2P 融 宜宝 - have lost billions of yuan each through defaults and fraudulent activity. ${ }^{5}$ Unlike traditional state-owned banks, these private operations come with no implicit guarantees. So when they fail, investors lose money. However, it seems that many investing in the funds don't fully understand this, or they conflate private lenders with 
state-supported financial institutions that are assumed to be protected from failure by the government.

The dramatic fall of Ezubao in late January 2016 served as a wake-up call. Ezubao had run advertisements on CCTV, and drew on the Party's discourse on its website. The company was conscious of the importance of being perceived as a state-supported organisation, and therefore held its 2015 annual meeting in the Great Hall of the People, with CCTV hosts and government officials in attendance. However, underneath this veneer of official legitimacy, the company was essentially a multi-billion-dollar Ponzi scheme. Ezubao claimed to be a P2P lending platform, offering products for investors with returns of up to fifteen percent annually - substantially higher than the rates offered by state-owned banks. This drew in close to one million investors. However, the vast majority of the products were fake, and founder Ding Ning 丁宁 drew on the funds as if the platform were his personal bank account. When Ezubao collapsed in January, its clients lost their investments (in some cases, millions of yuan) and many of the company's employees went unpaid. ${ }^{6}$

\section{Regulatory Tensions: Controlling Financial (In)stability}

The spectre of high-profile cases of fraud and deception of this kind have caused unease for the Party-state. After years of non-interference in the industry, in 2015, the People's Bank of China (PBoC), along with a host of other government agencies, published the 'Guiding Opinions on Promoting the Healthy Development of Internet Finance'. This document aims to rein in the worst excesses of the open and free digital finance market with 'moderately loose regulatory policies'. ${ }^{7}$ The regulations require $\mathrm{P} 2 \mathrm{P}$ lenders to deposit their funds in a formally registered financial institution, rather than holding onto the money themselves, thereby integrating the $\mathrm{P} 2 \mathrm{P}$ market into the formal financial system. They also give the China Banking Regulatory Commission 中国银行业监督管理委 员会 (CBRC) the power to oversee P2P lending. Previously, the P2P industry fell under the jurisdiction of a number of government agencies and regulatory bodies, and thus was able to slip through the regulatory cracks.

At the end of 2015, the CBRC issued a draft set of regulations for the P2P industry. In August 2016, after 


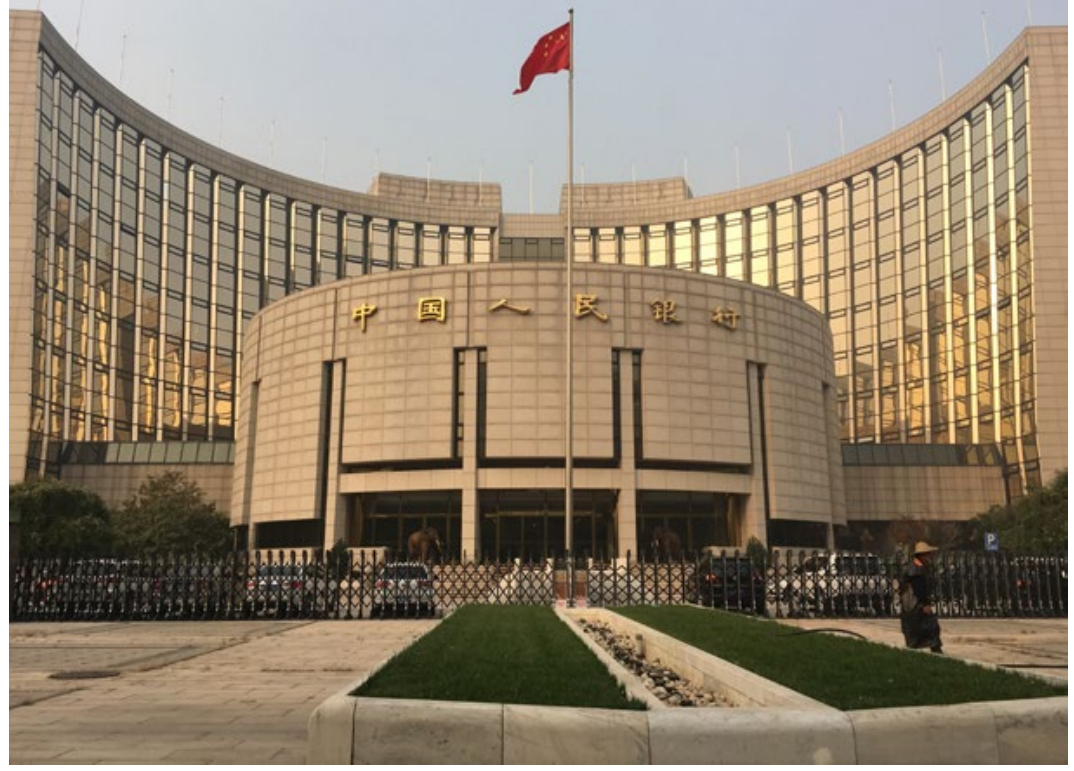

The People's Bank of China

Source: Wikimedia Commons

soliciting opinions on the draft, the CBRC, Ministry of Industry and Information Technology 工业和信息化部, Public Security Bureau 公安局, and State Internet Information Office 国家 互联网信息办公室 (along with a multitude of other agencies) formally promulgated the 'Interim Measures for the Management of the Business Activities of Internet Lending Intermediaries'. ${ }^{8}$ This policy is a direct response to the fraud committed by Ezubao and other lenders and aims to outlaw the more risky activities undertaken by $\mathrm{P} 2 \mathrm{P}$ platforms. In particular, it restricts P2P operators to serving as the intermediary for, rather than the provider of, financial services. Investment pooling, direct lending, crowdfunding, and other wealth management products traditionally provided by banks are limited or banned.
There is still plenty of wiggle room, however, particularly with regard to partnerships between P2P platforms and third parties, such as formally registered financial institutions. Also, the policy is more punitive than preventative. It does not establish minimum capital or licensing requirements, and emphasises self-regulation and reporting. ${ }^{9}$ In this way, the government is attempting to have it both ways. On the one hand, there is the explicit strategy to 'establish a sound, unified, and open nationwide market system ... to invigorate the market and turn the new benefits of reform into a new driving force for development' ${ }^{10}$ On the other, the government also feels compelled to control the industry in order to minimise risks inherent in this dramatic economic liberalisation. 


\section{Quantifying Social Quality}

The new regulations also require all P2P platforms to submit their data to the National Credit Reference Centre 征信中心, which assesses consumer and commercial credit ratings in China. The consolidation and centralisation of data from the P2P sector foreshadows the proposed establishment of a nationwide social credit system that will assess citizens based on their social and economic behaviour. In September 2016, the Central Committee and the State Council jointly issued a set of opinions on the construction of this system. ${ }^{11}$

The national social credit system would create a massive database compiling information about individuals and organisations in order to determine whether or not they are 'trustworthy'. While the opinions are not specific on how the system would be set up, or the exact criteria for determining 'trustworthiness', they do detail the myriad ways in which those with bad credit would be punished. In addition to being denied loans, 'trust-breakers' would face restrictions on the types of business they could engage in and the positions they could hold, limiting their eligibility for jobs in SOEs, the government, social organisations, and the financial industry. They would also be barred from acts of 'conspicuous consumption' including travelling first class, staying in luxury hotels, travelling overseas, enrolling their children in expensive schools, and even building houses or carrying out extensive home renovations. The stated aim is that honesty and trustworthiness should become the common values and normal behaviours for all society'. ${ }^{12}$ In this way, the Party-state intends for the social 
credit system to lay the foundations for a society based on 'joint governance' 共 同治理 and the 'rule of law’ 依法治国.

Unsurprisingly, the Western media has depicted the social credit system as the ultimate Orwellian nightmare. For instance, in an article published at the end of 2016, The Economist opines that the Chinese government 'is creating the capacity for a long-tentacled regime of social control ... If and when that is done, China would have the world's first digital totalitarian state'. ${ }^{13}$ While this observation may be true, the magazine somewhat undermines their hard opposition to Orwellian data collection by dismissing fears of the rise of surveillance in Western countries such as the UK, where the government passed the Investigatory Powers Act in November 2016, paving the way for 'extreme surveillance'. ${ }^{14}$ Readers are assured, without the slightest hint of irony, that 'you can be fairly sure that the West will have rules - especially where the state is involved'. ${ }^{15}$

What these attempts at Big Data collection by governments in both China and the West indicate is that we are now truly in the age of global surveillance, with many countries including the UK, the US, and Australia collecting metadata and other information on their citizens regardless of whether they are suspected of a crime. Writing about an earlier outline of the proposed social credit system, the New York-based economist Sara Hsu points out that details of its implementation remain vague, and attributes much of the handwringing to the overactive imaginations of 'China watchers' ${ }^{16}$ It is true that, like most central policy outlines, this one is imprecise in its language and open to flexible interpretation at the local level. For instance, while the opinion outlines some possible punishments for 'trust-breaking', it also suggests that lower levels of government can come up with other sanctions, thus allowing for local policy experimentation.

As it often does with major policy proposals, the government has given the green light to small-scale pilot projects involving social credit systems. Dozens of municipal governments, including Hangzhou and Shanghai, have developed their own. ${ }^{17}$ The government has also permitted eight private Internet companies to create social credit measures for use with their own products and the products of their business partners. For instance, China Rapid Finance 信而富 employs a team of investigators who take pictures of prospective borrowers at work and visit their homes in order to assess credit 
worthiness, while Welab's Wolaidai 我来贷 compiles information gleaned from mobile phone usage (with the permission of potential borrowers) to determine credit scores. Tencent 腾讯 and Baidu 百度 are also said to be developing social credit scores based on Internet activity, including online purchases and even search histories. ${ }^{18}$ Sesame Credit, meanwhile, has the benefit of utilising the big data vacuumed up by Alipay 支付宝, owned by their parent company Ant Financial 蚂蚁金服 (part of the Alibaba Group 阿里巴巴集 团), which controls over eighty percent of China's online payment market, to produce credit scores based on shopping habits, bill payments, travel, and so on. The credit scores created by Sesame Credit are utilised by a number of other businesses, such as online dating websites and rental companies, to either provide perks or refuse service. ${ }^{19}$

Sesame Credit scores are also used in Alipay's new app, Daowei 到位, which seeks to apply the Uber business model to a large number of entrepreneurial activities - traditionally the domain of formally registered enterprises - by allowing private individuals to enter the market and compete for customers. Those with high enough credit scores can use the app to offer

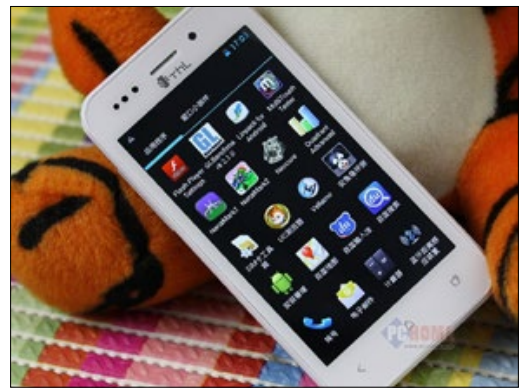

Information is gleaned from mobile phone usage to determine credit scores

Source: Yang Long, Flickr

or request a range of services or products, ${ }^{20}$ helping to transform 'trustworthy' citizens into micro-entrepreneurs. In many ways, this is the realisation of a neoliberal vision of an open, free, and 'pure' market - the imagined village of Adam Smith, where the baker and the fishmonger trade their wares for mutual benefit, coming to fruition in the context of contemporary China's digital space. Of course, how 'free' you are depends on your social credit rating.

The social credit system ties in with China's ‘civilisation' 文明 project (see the China Story Yearbook 2013: Civilising China, Introduction 'Engineering Chinese Civilisation', pp.xxxix), which aims to increase the 'quality' 素质 of 'less developed' segments of the population. The policy explicitly states that those without good social 
credit will be ineligible for honorary titles such as 'civilised household' 文 明家庭. ${ }^{21}$ In this way, credit scores designate who is and is not a model citizen, and provide instruction for how to become 'civilised' and 'trustworthy'. Credit scores are also couched in the language of scientism. Opaque algorithms coldly calculate 'objective' scores that are supposedly detached from the biases implicit in human decision making. This gives the illusion that individuals are in control of their scores, as it is their behaviour that determines the rights they will be granted in China's perpetually emerging 'harmonious society'.

\section{Fractured Control in China's Digital Space}

These examples of how Internet finance facilitates multifaceted forms of control in China's digital landscape should prompt us to question two-dimensional accounts depicting digital development as either empowering the 'grassroots' (and democracy) or abetting the monolithic state's thirst for control over its citizens. Rather, the rapid development of Internet finance has given rise to fractured and layered patterns of domination and liberation.
It has opened up new opportunities for large segments of society, while also producing new types of indebtedness, and associated forms of exploitation and violence - including literal claims over the bodies of the indebted.

Regulators attempt to balance the urge to control with the desire to allow the type of 'free' market they believe is necessary to spur on China's ceaseless need for socioeconomic development. All the while, the government is creating a nationwide social credit system that will use a financialised and 'scientific' logic to engineer a 'trustworthy' and 'harmonious' society.

This raises larger questions about who and what is actually controllable in contemporary China. For example, does the government have the ability to effectively govern the digital financial sphere? This question is especially relevant as loosely regulated Internet financial operators become more and more integrated into the largely stateowned formal financial sector. P2P lenders are teaming up with stateowned banks to provide financial services. ${ }^{22}$ Internet companies such as Alibaba, Tencent, Sina 新浪, and Baidu are displacing formal banks by launching online investment funds that have attracted hundreds of billions of yuan; 


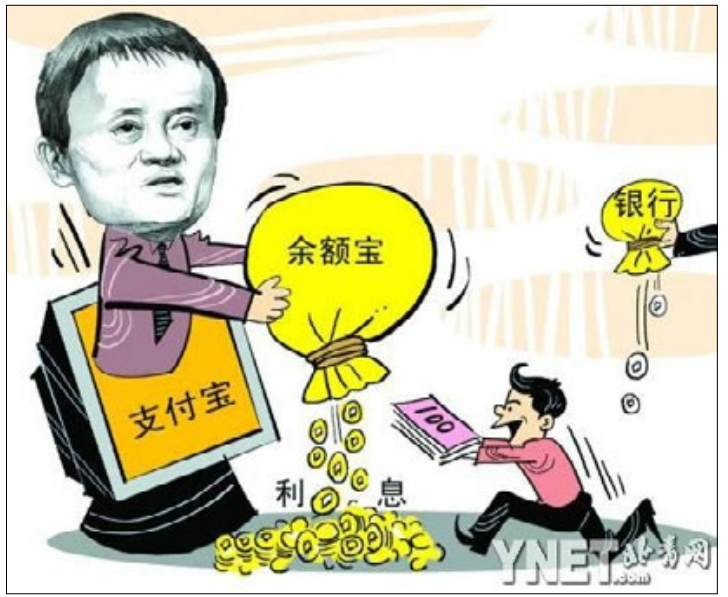

Alibaba's Yu'ebao: 'a bloodsucking vampire' Source: Beijing Youth Daily

and even the National Social Security Fund 全国社会保障基金理事会 has invested in the online Ant Financial. These are funds that would have traditionally been handled by the stateowned banking system, but are now being managed by private investment companies - a situation that prompted the CCTV commentator Niu Wenxin 钮文新, to liken Alibaba's Yu'ebao to a 'blood-sucking vampire'.

The international media, which has more freedom to discuss such possibilities, has published a number of stories warning that risky lending for speculative investments, as has been common in the digital financial sphere, may lead to a major financial crash. This begs the question of how the current system will weather the integration of loosely regulated and inherently risky Internet finance providers into the larger, state-controlled system.

The centralised social credit system raises additional questions about data security, as it is a prime target for hackers seeking to access, steal, or manipulate personal information. ${ }^{23}$ It has also broken the mould of China's distinctive policy development process. Traditionally, new central policies are first piloted at lower levels of government. However, both local governments and private companies are piloting the social credit system, potentially giving rise to tensions over its ownership.

Most important is the question of the impact of this dynamic digital financial sphere, including the evolving social credit system, on the lives of the Chinese people. Will it result in a more egalitarian spread of resources and allow people to take more control over their destiny? Or will it simply serve to consolidate control and further calcify already existing socioeconomic divisions and hierarchies of power? 
This text is taken from China Story Yearbook 2016: Control, edited by Jane Golley, Linda Jaivin and Luigi Tomba, published 2017 by ANU Press, The Australian National University, Canberra, Australia. 